\title{
Blood Cell Morphology and Plasma Biochemistry of Captive Mauremys caspica (Gmelin, 1774) and Mauremys rivulata (Valenciennes, 1833)
}

\author{
K. METIN ${ }^{1}$, Y. BAŞIMOĞLU KOCA ${ }^{1}$, F. KARGIN KIRAL ${ }^{2}, \mathrm{~S}_{\text {KOCA }}$, \\ O. TÜRKOZAN \\ ${ }^{1}$ Department of Biology, Faculty of Science and Arts, \\ ${ }^{2}$ Department of Biochemistry, Faculty of Veterinary Medicine, Adnan Menderes University, Aydın, Turkey
}

Received February 9, 2007

Accepted February 14, 2008

\begin{abstract}
Metin K., Y. Başımoğlu Koca, F. Kargın Kıral, S. Koca, O. Türkozan: Blood Cell Morphology and Plasma Biochemistry of Captive Mauremys caspica (Gmelin, 1774) and Mauremys rivulata (Valenciennes, 1833). Acta Vet. Brno 2008, 77: 163-174

Morphological characteristics of peripheral blood cells, micronucleated erythrocyte counts and plasma biochemistry profile were examined in fourteen healthy captive Mauremys caspica and in twenty-three Mauremys rivulata. The size of erythrocyte cells were $19.07 \times 11.68 \mu \mathrm{m}$ and 19.76 $\times 11.44 \mu \mathrm{m}$ for $M$. caspica and $M$. rivulata, respectively. Nucleus sizes were $6.50 \times 5.30 \mu \mathrm{m}$ for $M$. caspica and $6.79 \times 5.45 \mu \mathrm{m}$ for $M$. rivulata. The micronucleated erythrocyte (MNE) values were 0.0008 and 0.0037 for the males and females of $M$. caspica, respectively. The MNE values were 0.0002 for male and female $M$. rivulata.

We found sex-dependent differences only in the $\mathrm{Ca}$ value in the blood biochemistry profile for healthy $M$. caspica. Sex-dependent differences were found only in albumin and $\mathrm{P}$ values in the blood biochemistry profile for healthy $M$. rivulata. No significant differences were found between males of both species in question with respect to plasma biochemistry values. However, only plasma total protein and $\mathrm{Ca}$ content levels differed significantly between the females of the two species.
\end{abstract}

Reptilia, haematology, micronucleus, sex, plasma indicators, Ca, P, enzymes, albumin, urea

Turtles inhabit all parts of the world with a temperate to warm climate and are especially abundant in the tropics and subtropics. Water turtles are found in a wide variety of habitats, including ponds, swamps, small pools thick with vegetation, lakes of all sizes, large streams and rivers.

Blood biochemistry profiles and haematology are often used to assess the physiological status of lower vertebrate patients, such as fish, amphibians, reptiles, and birds. However, there is a general lack of controlled studies designed to clarify the meaning of changes in the blood chemistry of these animals compared to those of domestic mammals. Therefore, the clinical chemistry of lower vertebrates has not achieved the same degree of critical evaluation as demonstrated in domestic mammalian medicine. Many papers characterize the blood of land tortoises (Duguy 1970; Lawrence and Hawkey 1986; Garner et al.1996; Muro et al.1998; Christopher et al. 1999; Knotková et al. 2002), however, freshwater turtles are little known as to their haematology and blood biochemistry (Pagés et al. 1992; Kölle et al. 1999; Uğurtaş et al. 2003; Metin et al. 2006). Comparative studies of clinically healthy and diseased turtles may provide useful information for their management and conservation (Bolten and Bjorndal 1992; Hasbun et al. 1998). Understanding the blood composition of turtles is very important for preventing and treating many illnesses as well.

Many animal species can be used as bioindicators, either for testing the effects of some chemicals in laboratory strains, or for assaying natural populations to investigate the 
presence of pollution in a territory (Cristaldi et al. 2004). The micronucleus test detects the effect of mutagenetic agents on chromosomes by the identification of acentric fragments or lagging chromosomes, those remaining separate from the nucleus (Zuniga-Gonzalez et al. 2000). The scoring of $\mathrm{MN}$ is simpler, requires shorter training and is less timeconsuming.

Although many studies have been made on the haematology of reptiles, blood cell morphology and plasma biochemistry and micronucleus for many species are not available. Various authors have described different circulating blood cells of different reptile species (Duguy 1970; Mateo et al. 1984; Canfield and Shea 1988; Knotková et al. 2002; Azevedo and Lunardi 2003; Başımoğlu Koca et al. 2006; Metin et al. 2006). Identification of morphologic characteristics of different peripheral blood cells and plasma biochemistry profile of $M$. caspica and $M$. rivulata kept in captivity was the purpose of this study.

\section{Materials and Methods}

\section{Animals}

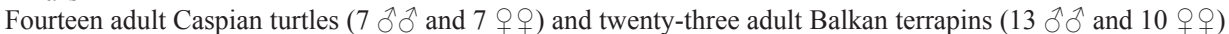
were studied on a private captive breeding farm in the month of July. The specimens were kept in vessels ( $200 \times$ $200 \times 60 \mathrm{~cm})$ at the farm and fed commercial trout food, dog food, sardines, anchovies, chopped chicken liver and sheep stomach. The mean straight carapace lengths of both species were measured. The females were checked by manual examination through the cloaca for eggs in oviducts. All of them were determined as non-pregnant.

Blood sampling

Plasma biochemistry analyses and blood cell morphology were analyzed in 14 adult $M$. caspica $(7 \hat{\jmath}, 7$ 우) and 23 adult $M$. rivulata $(13 \hat{\delta} \hat{\jmath}, 10$ 웅). Blood specimens of two turtle species were taken by venepuncture from caudal vein. Blood (1-2 ml) was collected using 21 gauge needles and $5 \mathrm{ml}$ syringes. Blood specimens were transferred into vacutainer tubes containing lithium heparin and placed on ice until processing in the laboratory 4-6 h after capture. Plasma was separated by centrifugation at $800 \mathrm{~g}$ for $10 \mathrm{~min}$ (Nüve NF $800 \mathrm{R}$, Turkey) and split in two or more vials.

Blood cell morphology

Blood samples were taken from the caudal vein. Blood smears were prepared immediately and air-dried. Wright stained blood smears were used for the measurement and assessment of blood cells. Four to five blood smears were prepared per individual. On each slide lengths (EL) and widths (EW) of randomly selected 100 mature erythrocytes and their nuclei (NL and NW), 50 thrombocytes, heterophils, eosinophils, basophils, lymphocytes and monocytes were measured by an Olympus ocular micrometer at a magnification of $\times 600$ (Olympus BX51, Japan). Erythrocyte and nuclear sizes (ES and NS) were calculated according to formulas $[(\mathrm{EL} \times \mathrm{EW} \times \pi) /$ 4] and $[(\mathrm{NL} \times \mathrm{NW} \times \pi) / 4]$, respectively. In addition, micronucleated erythrocytes were counted among 1000 erythrocytes on each blood smear by the same micrometer at a magnification of $\times 1000$.

Plasma biochemistry

Biochemical indices of plasma were measured spectrophotometrically (Microlab, Merck 200, Deutschland) by means of commercial kits (Biomedical Biosystems/Spain). $\mathrm{Na}, \mathrm{K}$ and $\mathrm{Cl}$ were measured by means of an ion-selective device (Ion selective, Easy lite, England). Samples that appeared haemolysed were discarded. The following plasma was measured: aspartate aminotransferase (EC 2.6.1.1; AST), alanine aminotransferase (EC 2.6.1.2; ALT), gamma glutamyl transferase (EC 2.3.2.2; GGT), amylase (EC 3.2.1.1), total protein, albumin, globulin, glucose, creatinine, urea, triglycerides, cholesterol, $\mathrm{Ca}, \mathrm{P}, \mathrm{Na}, \mathrm{K}$ and $\mathrm{Cl}$. In addition, calculated values included globulin and albumin/globulin. Blood chemical values are expressed in SI units.

\section{Statistical analyses}

Haematological and biochemical indicators were summarized as mean, standard deviation (SD), standard error of the mean (SEM) and range. We used analysis of variance (ANOVA) and $t$-test for comparison between sexes within species, and between species within sex. Results were considered significant at $p<0.05$. Statistical analyses were carried out by using STATISTICA version 6.0.

\section{Results}

\section{Body size}

The mean straight carapace lengths (SCL) of $M$. caspica and $M$. rivulata were measured $14.53 \pm 3.74 \mathrm{~cm}$ and $15.02 \pm 2.86 \mathrm{~cm}$ for males, $18.20 \pm 3.17 \mathrm{~cm}$ and $15.60 \pm 1.87 \mathrm{~cm}$ for females, respectively. Body size distributions between genders in both species were not 


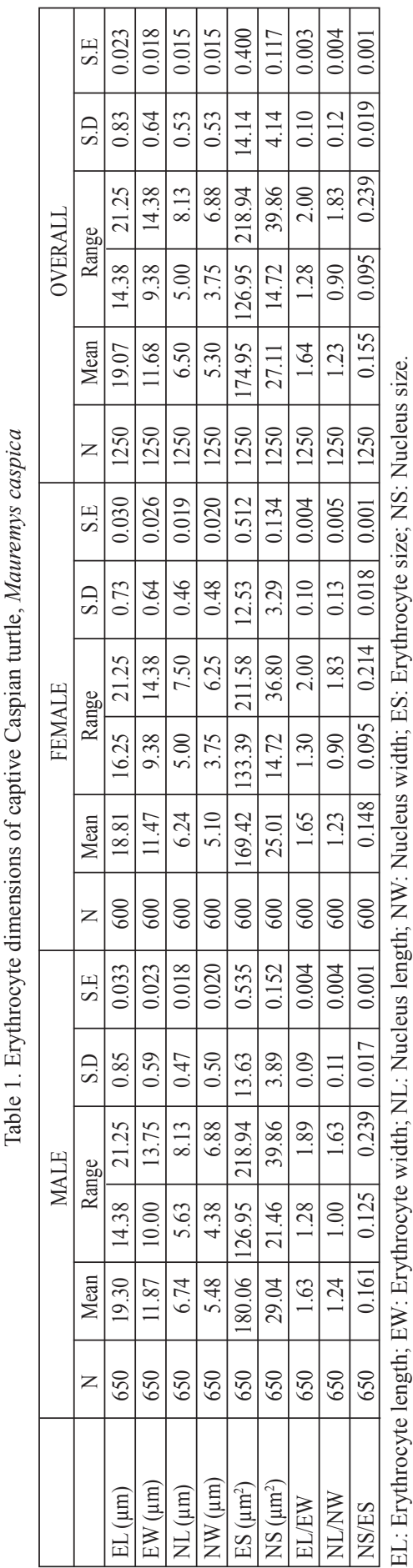

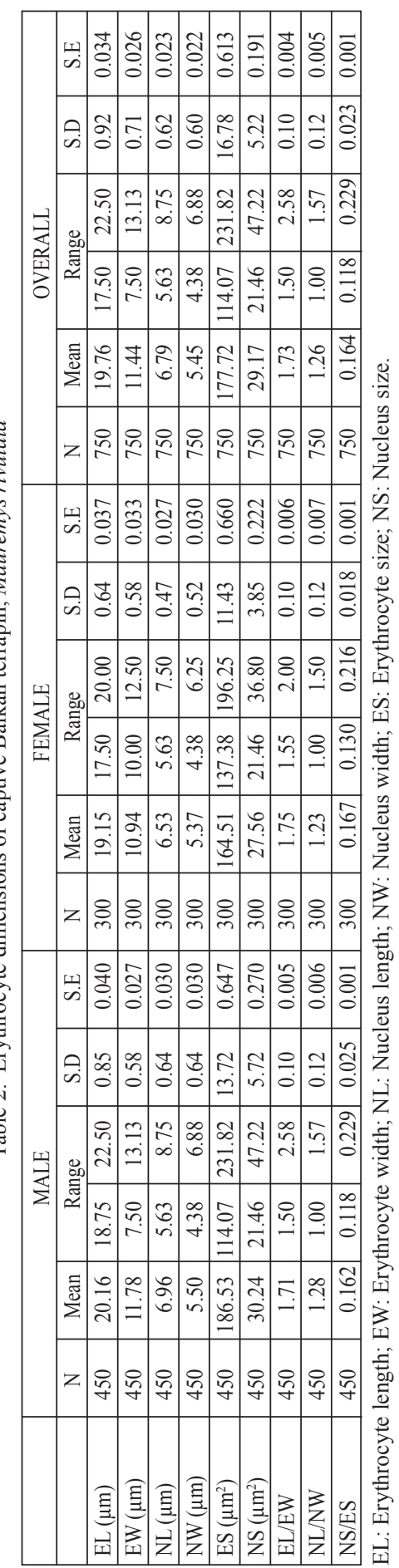




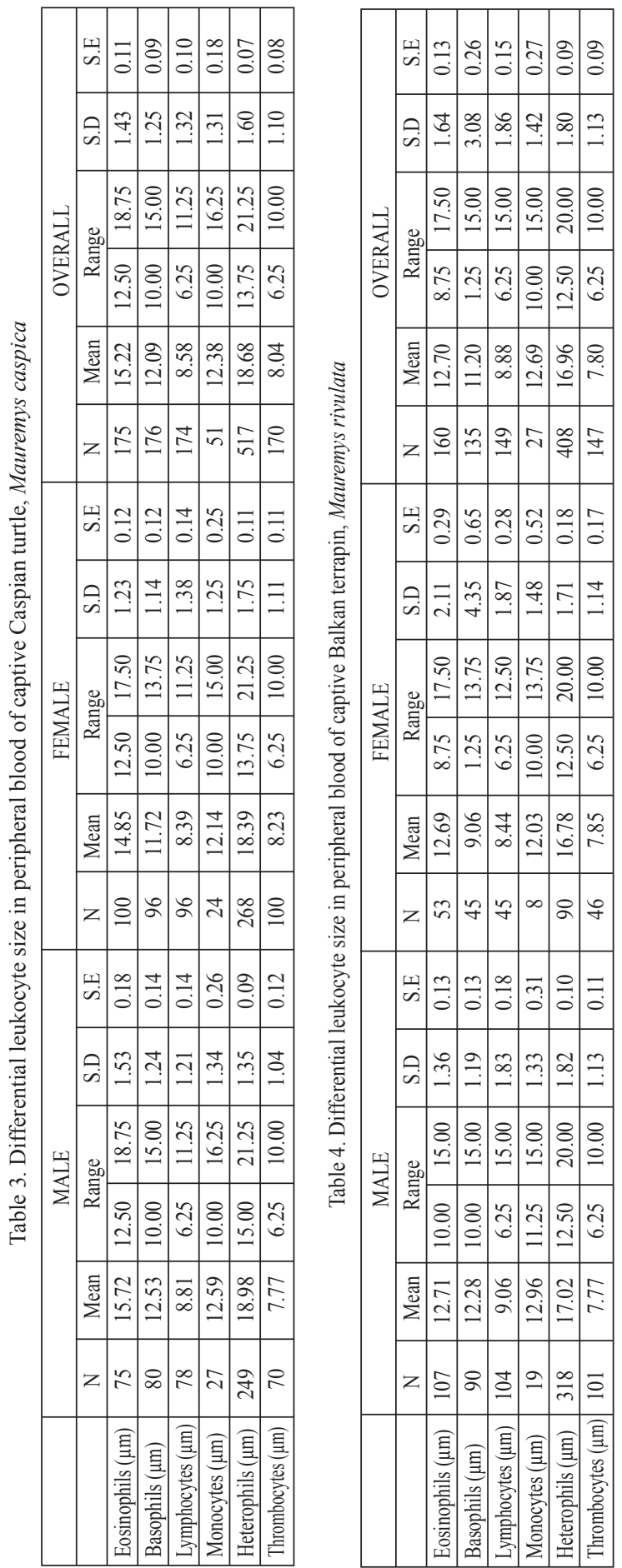

significantly different $(p>0.05)$. Therefore, the effect of size was independent of the effect of sex on the blood chemistry values.

Blood cell morphology

Mature erythrocytes of captive $M$. caspica and M. rivulata were nucleated ellipsoidal cells with pink cytoplasm and their nuclei were centrally located and stained dark purple (Plate I, Figs 1A, B, C, E; Plate II, Figs 2A, B, C, D, E). The size of erythrocyte cells were $19.07 \pm 0.83 \mu \mathrm{m} \times 11.68 \pm 0.64$ $\mu \mathrm{m}$ and $19.76 \pm 0.92 \mu \mathrm{m} \times 11.44$ $\pm 0.71 \mu \mathrm{m}$ for $M$. caspica and $M$. rivulata, respectively. The nucleus size was $6.50 \pm 0.53 \mu \mathrm{m} \times 5.30 \pm$ $0.53 \mu \mathrm{m}$ for M. caspica and $6.79 \pm$ $0.62 \mu \mathrm{m} \times 5.45 \pm 0.60 \mu \mathrm{m}$ for $M$. rivulata.

The nuclei of mature erythrocytes for two species were chromatophilic under the Wright stain. One-way ANOVA verified sexual dimorphism in terms of EL $(\mathrm{F}=119.1493 ; p<0.0001), \mathrm{EW}$ $(\mathrm{F}=138.5418 ; p<0.0001), \mathrm{NL}$ $(\mathrm{F}=360.0780 ; p<0.05), \mathrm{NW}(\mathrm{F}$ $=183.2911 ; p<0.0001), \mathrm{ES}(\mathrm{F}$ $=205.3256 ; p<0.0001)$ NS $(\mathrm{F}=$ $387.7125 ; p<0.0001)$, EL/EW $(\mathrm{F}=9.2539 ; p<0.0001)$ and NS/ ES $(186.61 ; p<0.0001)$ for $M$. caspica. Furthermore, M. rivulata also showed sexual dimorphism in terms of EL $(\mathrm{F}=307.2825 ; p$ $<0.0001)$, EW ( $\mathrm{F}=376.4450$; $p<0.0001), \mathrm{NL}(\mathrm{F}=99.5237$; $p<0.05)$, NW $(\mathrm{F}=8.6404 ; p<$ $0.0001), \mathrm{ES}(\mathrm{F}=528.2338 ; p<$ $0.0001) \mathrm{NS}(\mathrm{F}=50.4297 ; p<$ $0.0001)$ and $\mathrm{EL} / \mathrm{EW}(\mathrm{F}=28.9122$; $p<0.0001), \mathrm{NL} / \mathrm{NW}(\mathrm{F}=30.3329$; $0.0001)$ and NS/ES (11.016; $p<$ $0.0001)$. Results of erythrocyte measurements of $M$. caspica and $M$. rivulata are summarized in Tables 1 and 2, respectively. Interspecific differences in 


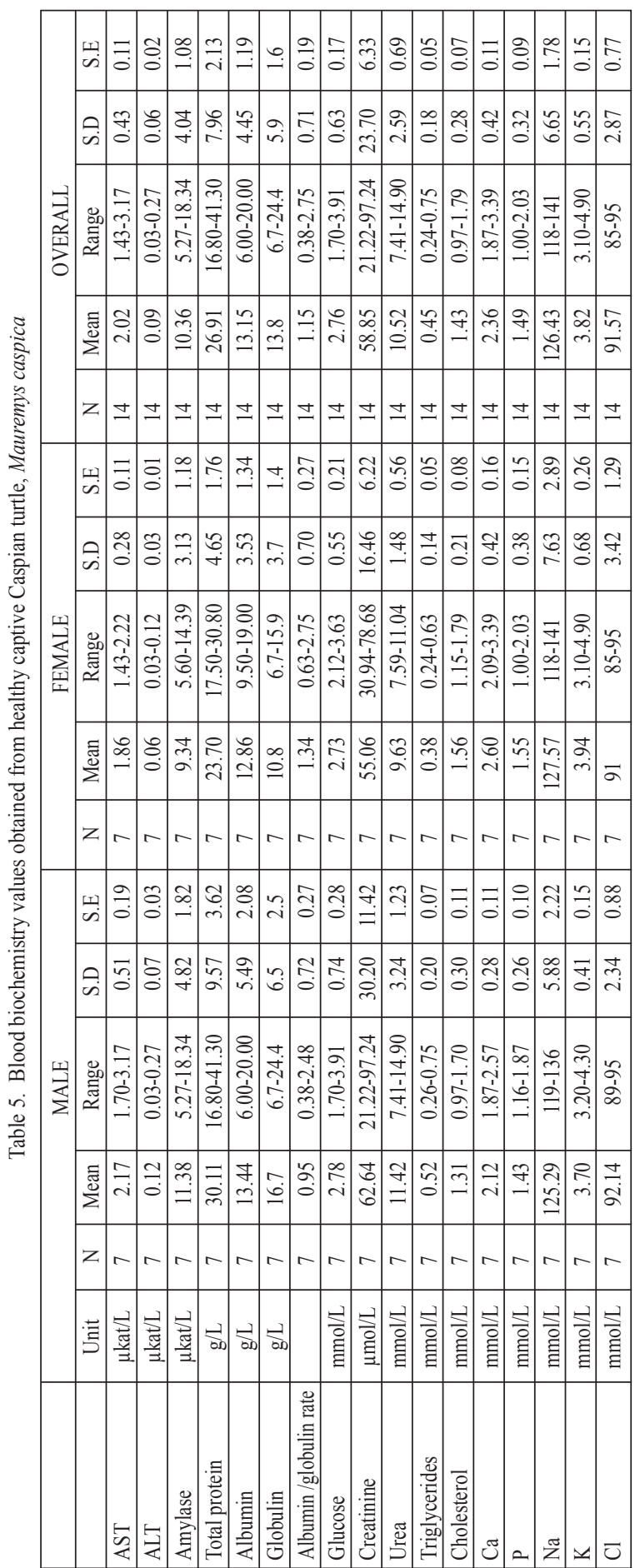

erythrocyte and nuclei sizes were tested separately for males and females of $M$. caspica and $M$. rivulata with ANOVA again. In males, all variables, except NW and NS/ES were significantly different $(p<0.0001)$ between two species. In females, except $\mathrm{NL} / \mathrm{NW}$, all measured variables were statistically different $(p<$ 0.0001).

Five types of leucocytes were identified for $M$. caspica and $M$. rivulata as heterophil, eosinophil, basophil, lymphocyte and monocyte (Figs 1, 2). The descriptive statistics of the leucocytes are presented in Tables 3 and 4. Heterophils were easily identified by the presence of numerous elongated pinkred cytoplasmic granules. These granules were hardly packed in the cytoplasm. The nucleus was round, oval or mostly bilobed and eccentric (Fig. 1A). The nucleus of eosinophils was sometimes bilobed and eccentrically placed. The cytoplasm was filled with deep eosinophilic round granules (Fig. 1B). Basophils were smaller than heterophils and eosinophils. Basophils were characterized by the presence of round basophilic (dark blue) granules of various sizes. The round nucleus was in the centre of the cell (Fig. 1C). Lymphocytes had a compact, large and dark, centrally positioned nucleus. Light-blue thin cytoplasm covered a narrow area around the nucleus (Fig. 1D). The monocytes mostly had a kidney-shaped nucleus, which was less intense chromatin than in lymphocytes. The cytoplasm of monocyte was blue-grey and covered a larger area (Fig. 1E). Thrombocytes often clump together in blood smears. The nucleus of thrombocytes was 


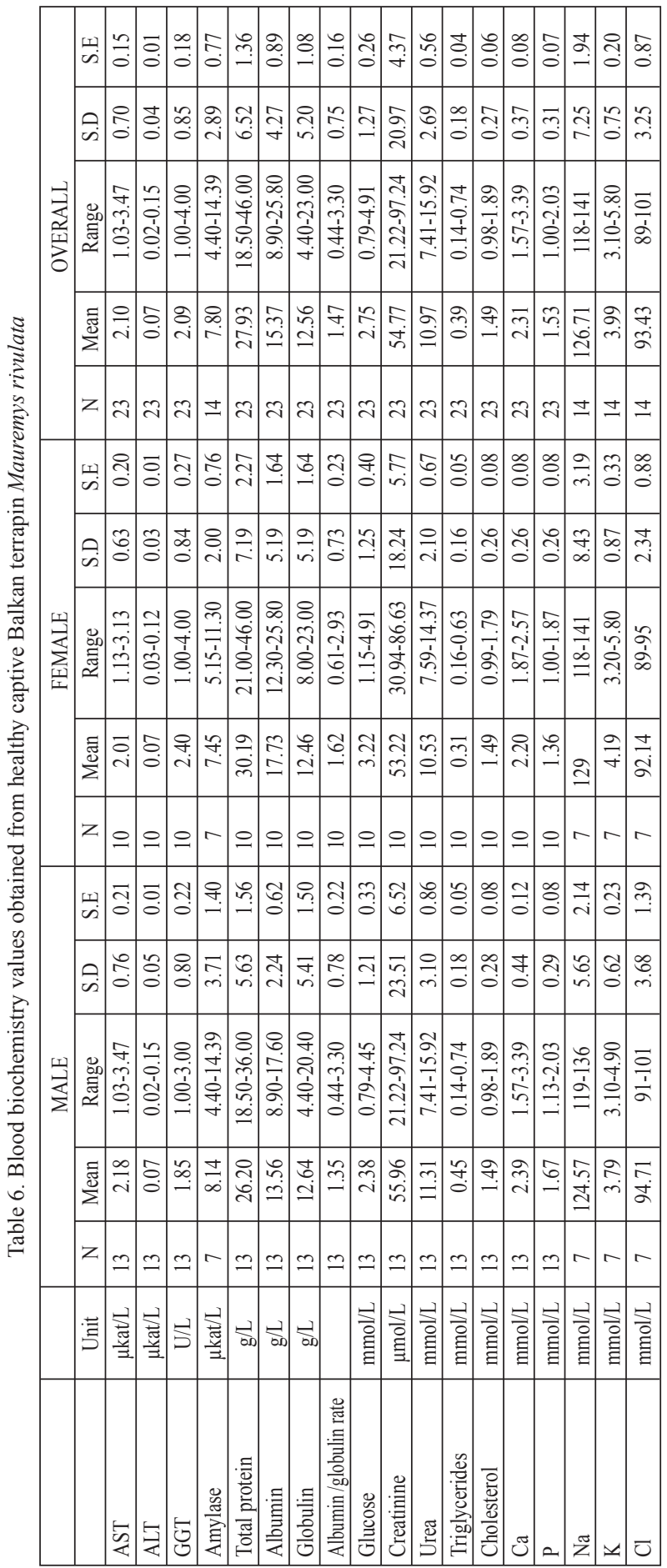

round or oval and dark. The cytoplasm was blue-purple and positioned around the nucleus (Fig. 1F).

Leukocytes of $M$. caspica and $M$. rivulata were measured in diameter. ANOVA verified intraspecific difference in leukocytes of $M$. rivulata. The diameter of basophils was smaller in females ( $F$ $=$ 43.22, $p<0.0001)$ in comparison to males. In $M$. caspica, all leukocytes were sex-dependent, except for monocytes. All diameters were smaller in females except for thrombocytes. Interspecific comparison of males proved smaller eosinophils ( $\mathrm{F}=$ 195.10, $p<0.0001)$ and heterophils $(\mathrm{F}=201.95, p$ $<0.0001)$ in $M$. rivulata. Almost the same cases were recorded in females having smaller eosinophils ( $\mathrm{F}=$ $63.74 p<0.0001$ ), heterophils $(\mathrm{F}=57.82, p<0.0001)$ and basophils $(\mathrm{F}=31.65, p<$ $0.0001)$ in $M$. rivulata. The sizes of leukocytes for these species were summarized in Tables 3 and 4.

\section{Plasma biochemistry}

We found significant differences only in the $\mathrm{Ca}$ value between genders in the blood biochemistry profile of healthy $M$. caspica. The mean $\mathrm{Ca}$ value was significantly higher in females $(2.60 \pm 0.42$ $\mathrm{mmol} / \mathrm{l})$ than males $(2.12 \pm$ $0.28 \mathrm{mmol} / \mathrm{l})(\mathrm{t}=-2.49 ; \mathrm{df}$ $=12 ; p<0.05)$. Results of plasma biochemistry analyses are summarized in Table 5.

Sex-dependent differences were found only in albumin and $\mathrm{P}$ values in the blood biochemistry profile of 
healthy $M$. rivulata. The mean albumin value was significantly higher in females $(17.73 \pm$ $5.19 \mathrm{~g} / \mathrm{l})$ than in males $(13.56 \pm 2.24 \mathrm{~g} / \mathrm{l})(\mathrm{t}=-2.61 ; \mathrm{df}=21 ; p<0.05)$. Nevertheless, the mean $\mathrm{P}$ value was significantly higher in males $(1.67 \pm 0.29 \mathrm{mmol} / \mathrm{l})$ than in females $(1.36$ $\pm 0.26 \mathrm{mmol} / \mathrm{l})(\mathrm{t}=-2.67 ; \mathrm{df}=21 ; p<0.05)$. Results of plasma biochemistry analyses are summarized in Table 6.

No significant differences were found between males of both species in question with respect to plasma biochemistry values. However, only plasma total protein and $\mathrm{Ca}$ content levels differed significantly between females of the two species. The mean total protein value was significantly higher in $M$. rivulata $(30.19 \pm 7.19)$ than in $M$. caspica $(23.70 \pm 4.65 \mathrm{~g} / \mathrm{l})\left(\mathrm{F}_{(1.12)}=\right.$ $4.90, p<0.05)$. However, the mean Ca value was significantly higher in $M$. caspica $(2.60 \pm 0.42$ $\mathrm{mmol} / \mathrm{l})$ than in $M$. rivulata $(2.20 \pm 0.26 \mathrm{mmol} / \mathrm{l})\left(\mathrm{F}_{(1,12)}=5.89, p<0.05\right)$.

Micronucleated erythrocytes (MN)

The micronucleated erythrocyte (MNE) values of $M$. caspica were 0.0008 for the males and 0.0037 for the females; the (MNE) values of M. rivulata were 0.0002 and 0.0002 for the males and females, respectively. The micronucleated erythrocyte (MNE) values of $M$. caspica and M. rivulata are given in Table 7.

Table 7. Micronucleated peripheral erythrocytes of captive Caspian turtle, Mauremys caspica and Balkan terrapin, Mauremys rivulata

\begin{tabular}{|l|c|c|c|c|}
\hline \multirow{2}{*}{ Species } & Gender & $\mathrm{N}$ & $\begin{array}{c}\text { Individual animal counts/1000 } \\
\text { erythrocytes }\end{array}$ & $\begin{array}{c}\text { Micronucleated } \\
\text { erythrocyte/1000 }\end{array}$ \\
\hline \multirow{2}{*}{ M. caspica } & Male & 5 & $2 / 1 / 0 / 1 / 0$ & 0.0008 \\
\cline { 2 - 5 } & Female & 5 & $2 / 4 / 6 / 3$ & 0.0037 \\
\hline \multirow{2}{*}{ M. rivulata } & Male & 4 & $1 / 0 / 0 / 0$ & 0.0002 \\
\cline { 2 - 5 } & Female & 4 & $0 / 1 / 0 / 0$ & 0.0002 \\
\hline
\end{tabular}

\section{Discussion}

One of the most important functions of erythrocytes is to carry oxygen and carbon dioxide, and its surface area to size ratio is also a determining factor in the tissues. Thus, a small erythrocyte offers the possibility of a higher rate of exchange than a larger one (Hartman et al. 1964; Sevinç et al. 2000). According to Wintrobe (1933) the erythrocyte size reflects the position of a species on the evolutionary scale: in lower vertebrates and those with a not-so successful evolutionary past, i.e. in cyclostomes, elasmobranches and urodeles, the erythrocytes are large, but in higher vertebrates (mammals) the same cells are smaller and do not contain nuclei.

Erythrocytes are morphologically similar among various species of reptiles (Saint Girons 1970). The erythrocytes of Russian tortoises, Agrionemys horsfieldi, were reported to be long or irregular in shape (Knotková et al. 2002). Uğurtaş et al. (2003) pointed out a positive correlation between erythrocyte size and nucleus size for individuals belonging to families Testudinidae and Emydidae (Testudinidae: $\mathrm{r}=0.494, p<0.001$; Emydidae: $\mathrm{r}=0.668, p<0.001)$. Similar results were obtained for individuals belonging to family Scincidae $(\mathrm{r}=0.302, p<0.01)$ (Atatür et al. 2001). We also found positive correlation $(\mathrm{r}=0.61 p<0.05)$ by pooling $M$. caspica and M. rivulata together as Bataguridae family.

Nucleus in mature erythrocyte is round in green turtles (Chelonia mydas) (Samour et al. 1998). The only blood cell values that were comparable to those of some natural terrapins from Turkey were EL, EW, ES, EL/EW and NS/ES as taken from Uğurtaş et al. (2003). When the means of our blood cell values were tested with one sample $t$-test against the natural $M$. caspica and M. rivulata population means, the EW, ES EL/EW and NS/ES 
values were significantly different $(p<0.0001)$ from those of the captive population.

The classification of reptilian leukocytes poses many problems since these cells show morphological variation within the class and several different nomenclatures have been used to describe them (Knotková et al. 2002). For example, Taylor and Kaplan (1961) divided leukocytes into neutrophils, basophils, eosinophils, lymphocytes and monocytes on the basis of light microscopy in turtles. Saint Girons (1970) reported the presence of eosinophils, azurophils, neutrophils and plasma cells in reptiles, Sypek and Borysenko (1988) described eosinophils and heterophils in reptilian blood. Cannon et al. (1996) divided granulocytes into basophils and eosinophils on phase-contrast microscopy. Wood and Ebanks (1984) described eosinophils and neutrophils. Widely accepted opinion is that reptilian (Montali 1988) and avian heterophils (Brooks et al. 1996) have functions similar to mammal neutrophils.

According to Canfield (1998) the mammalian neutrophil is equivalent to the nonmammalian heterophil. The heterophil, excluding mammals, has coarse, red to brown, speculated to irregular granules of variable size and either a bilobed (birds and some lizards) or unlobed nucleus (most reptiles and amphibians). Azevedo and Lunardi's (2003) observations show that 2 types of eosinophilic granulocytes are present in blood of Chrysemys dorbigni. Eosinophils and neutrophils are granulocytic leukocytes present in the blood of most vertebrates. The existence of these two cell types in reptiles is a matter of controversy. To avoid confusion, some researchers suggest that the term neutrophils be restricted to mammals and the term heterophil to non-mammals (Zapata et al. 1981; Canfield 1985). In fact Azevedo and Lunardi (2003) determined 2 types of eosinophilic granulocytes which are called type I and type II for Chrysemys dorbigni. After analyzing morphological characteristics of type I, it is seen that they are similar to those of eosinophils of some birds, and in comparison of cytochemical characteristics they are similar to those of eosinophils of both birds and mammals. Type II cells are morphologically similar to those of bird heterophils, and cytochemical characteristics are similar to those of neutrophils of birds and mammals.

In this study, it appears that on the basis of light microscopic findings there are three main types of granulocytes (heterophils, eosinophils, basophils) and two main types of agranulocytes (lymphocytes and monocytes) in M. caspica and M. rivulata (Figs. 1, 2). We identified heterophils as having an eccentrically placed nucleus and being round-oval or mostly bilobed in shape. The cytoplasm was filled with numerous elongated granules. The eosinophils in the present study had a blue round or oval nucleus. The nucleus sometimes consisted of two lobes and was eccentrically placed. The cytoplasm was pink-red and filled with deep eosinophilic round granules. Basophils were round and provided with a centrally positioned nucleus. The cytoplasm was filled with large rounded granules, the colour of which varied from dark blue to black. These basophilic granules partially masked the nucleus, as previously stated by Canfield (1998).

Lymphocytes may be small, medium or large. Canfield (1998) stated that cytoplasm may contain small vacuoles and azurophilic granules. In the present study, the nucleus of lymphocytes almost filled the cytoplasm of the cell. The amount of cytoplasm was lower and of light blue colour. Monocytes are large cells with unlobed or lobed nuclei and a large amount of lightly basophilic cytoplasm. Monocytes in captive $M$. caspica and $M$. rivulata had a mostly kidney-shaped nucleus, which was less intense and contained pale chromatin. The cytoplasm was grey blue and expanded over more area. Both species contained a higher amount of lightly basophilic cytoplasm in comparison to lymphocytes.

The similarity of thrombocytes and lymphocytes in reptiles is known (Saint Girons 1970; Frye 1991). Canfield and Shea (1988) reported that thrombocyte morphology was influenced by the degree of aggregation. Saint Girons (1970) reported that thrombocytes were small, oval cells characterized by elongate, centrally located, highly chromophilic 
nuclei. Knotková et al. (2002) identified two types of thrombocytes in Russian tortoises, Agrionemys horsfieldi: oval with a good visible membrane, a faintly stained cytoplasm; and rectangular with small projections of lightly basophilic cytoplasm. They attributed this variability to ageing, function and artifact. The similarity of thrombocytes and lymphocytes in reptiles is known (Frye 1991). The present study reports that thrombocytes are formed in cell groups, with centrally located dark-stained nuclei and their cytoplasm is difficult to see at the light microscopic level.

There was an only plasma $\mathrm{Ca}$ difference detected in the plasma biochemistries between genders in $M$. caspica. Calcium concentration was significantly higher in females than in males. However, plasma P value between genders was not significantly different; it was found to be higher in females than in males. The elevated $\mathrm{Ca}$ and $\mathrm{P}$ concentrations in female turtles were not unexpected. Female turtles routinely mobilize $\mathrm{Ca}$ and $\mathrm{P}$ during their reproductive cycle for egg production and vitellogenesis. Female reptiles exhibit features of Ca metabolism similar to those of birds during egg production. During egg development, female reptiles exhibit hypercalcaemia in response to oestrogen and reproductive activity. This situation shows that vitellogenesis and ovulation continued during the sampling period in females and they were very active metabolically.

M. rivulata showed sex-dependent difference as to albumin and $\mathrm{P}$. The $\mathrm{Ca}$ concentration was higher in males than in females (non-significant difference). This might be a sign of finishing ovulation and vitellogenesis in females. The higher albumin level could be the explanation of an active period during summer in females. These results coincide with previous studies. The seasonal fluctuations of the albumin concentration followed that of the total protein. It was the lowest in the spring, increased in the summer and peaking in the autumn. Active reptile species with a high metabolic rate have higher albumin concentrations (Masat and Dessauer 1968; Dessauer 1970).

The normal plasma concentration of $\mathrm{Ca}, \mathrm{P}$ and albumin for turtles and tortoises in the data found in literature ranges between $0.70-6.33 \mathrm{mmol} / \mathrm{l}, 0.67-4.45 \mathrm{mmol} / \mathrm{l}$ and 2.89 $18.4 \mathrm{~g} / \mathrm{l}$, respectively (Hutton and Goodnight 1957; Jackson et al. 1974; Mosquera et al. 1976; Taylor and Jacobson 1982; Jacobson et al. 1991; Bolten and Bjorndal 1992; Pagés et al. 1992; Kölle et al. 1999; Knotková et al. 2002; Metin et al. 2006). Plasma $\mathrm{Ca}, \mathrm{P}$ and albumin levels of both species in the present study were within the range reported for other turtles, although the normal plasma $\mathrm{Ca}, \mathrm{P}$ and albumin concentrations vary with the species and physiological status of the reptiles and most likely other ectotherms.

No significant differences were found between males of both species in question with respect to plasma biochemistry values. However, only plasma total protein and $\mathrm{Ca}$ content levels differed significantly between the females of the two species. The mean total protein value was significantly higher in M. rivulata than in M. caspica. However, the mean Ca value was significantly higher in $M$. caspica than in M. rivulata. The physiological plasma total protein concentration of lower vertebrates is generally lower than that of mammals. Female reptiles demonstrate a marked increase in the plasma total protein concentration during active folliculogenesis. The plasma total protein concentration returns to original values following ovulation. According to data found in literature, physiological plasma concentrations of total protein in turtles and tortoises range between $22-75 \mathrm{~g} / 1$ (Masat and Musacchia 1965; Taylor and Jacobson 1982; Jacobson et al. 1991; Bolten and Bjorndal 1992; Kölle et al. 1999; Knotková et al. 2002; Metin et al. 2006).

We compared the blood biochemistry values of $M$. caspica with the summer values of $M$. caspica leprosa (Pagés et al. 1992). The total protein, urea and Na values were not significantly different. However, albumin $(p<0.05)$, globulin $(p<0.001)$, albumin/ globulin ratio $(p<0.05)$, glucose $(0.0001), \mathrm{Ca}(0.0001), \mathrm{P}(0.0001)$ and $\mathrm{K}(p<0.05)$ values were significantly different. 
The micronucleus count is an indicator of a genetic damage in mature animals. An increased number of micronucleated cells indicate poor health. However, ZunigaGonzález et al. (2000) suggested that in the case of new-born animals the presence of MNE could be increased, since the reticuloendothelial system might be immature in the young of some species. They also noted that the reticuloendothelial system matures with age. In some reptile species such as Crocodylus acutus, Pituophis depei, Macroclemys temminckii (Zuniga-González et al. 2000), Emys orbicularis (Metin et al. 2006), Neurergus crocatus (Basimoglu Koca et al. 2006) very low or no MNE count was found.

The results of this study add new information to our knowledge of $M$. caspica and $M$. rivulata physiology and provide an important database for veterinarians, scientists, and biologists assessing tortoise medicine, ecology, and survival.

\section{Morfologie krevních buněk a plasmatické hodnoty biochemických ukazatelů želv chovaných v zajetí Mauremys caspica (želva kaspická, Gmelin, 1774) a Mauremys rivulata (Valenciennes, 1833)}

U čtrnácti zdravých, v zajetí chovaných želv kaspických a 23 Mauremys rivulata byla zjišt’ována morfologická charakteristika periferních krevních buněk, počty erytrocytů obsahujících mikronuclei a biochemický profil krevní plasmy. Velikost erytrocytů byla u $M$. caspica 19,07 × 11,68 $\mu \mathrm{m}$ a u $M$. rivulata $19,76 \times 11,44 \mu \mathrm{m}$. Velikosti jader byly $6,50 \times 5,30 \mu \mathrm{m}$ u $M$. caspica a $6,79 \times 5,45 \mu \mathrm{m}$ u M. rivulata. Počty mikronukleovaných erytrocytů (MNE) byly 0,0008 u samců a 0,0037 u samic $M$. caspica. U želv $M$. rivulata byl MNE 0,0002 jak pro samce tak i pro samice. Pouze u vápníku jsme pozorovali na pohlaví závislé rozdíly v biochemickém profilu u zdravých želv $M$. caspica. V biochemickém profilu zdravých želv $M$. rivulata byly takovéto rozdíly pozorovány pouze pro koncentrace albuminu a fosforu. U samců obou druhů želv nebyly pozorovány výrazné rozdíly v ukazatelích biochemického profilu. U samic těchto druhủ byly zjišsěny významné rozdíly pouze pro celkovou bílkovinu a vápník.

\section{Acknowledgement}

This study was supported by Adnan Menderes University grant with the number FEF-04004. The authors would like to thank the Tosbağa Animal Reproduction and Research Company for giving us permission to work on the animals.

\section{References}

ATATÜR MK, ARIKAN H, ÇEVIK E, MERMER A 2001: Erythrocyte measurements of some scincids from Turkey. Turk J Zool 25: 149-152

AZEVEDO A, LUNARDI LO 2003: Cytochemical characterization of eosinophilic leukocytes circulating in the blood of the turtle (Chrysemys dorbignih). Acta Histochem 105: 99-105

BAŞIMOĞLU KOCA Y, KOCA S, OLGUN K, BEYTAŞ P, ÜZÜM NT 2006: Blood cell morphology, erythrocyte size, and micronucleus counts of Neurergus crocatus (COPE 1862) (Urodela: Salamandridae) in Turkey. Russ J Herpetol 13: 83-88

BOLTEN AB, BJORNDAL KA 1992: Blood profiles for a wild population of green turtles (Chelonia mydas) in the southern Bahamas: size-specific and sex-specific relationships. J Wildl Dis 28: 407-413

BROOKS RL, BOUNOUS DI, ANDREASEN CB 1996: Functional comparison of avian heterophils with human and canine neutrophils. Comp Haematol Int 6: 153-159

CANFIELD PJ 1998: Comparative cell morphology in the peripheral blood film from exotic and native animals. Aust Vet J 76: 793-800

CANFIELD PJ 1985: Characterization of the blood cells of Australian crocodiles (Crocodylus porosus and C. johnstoni). Anat Histol Embryol 14: 269-288

CANFIELD PJ, SHEA GM 1988: Morphological observations on the erythrocytes, leukocytes and thrombocytes of blue tongue lizards (Lacertilia: Scincidae, Tiliqua). Anat Histol Embryol 17: 328-342

CANNON MS, FREED DA, FREED PS 1996: The leukocytes of the roughtail gecko Cyrtopodion scabrum: a bright-field and phase-contrast study. Anat Histol Embryol 25: 11-14

CHRISTOPHER MM, BERRY KH, WALLIS IR, NAGY KA, HENEN BT, PETERSON CC 1999: Reference 
intervals and physiologic alterations in hematologic and biochemical values of free-ranging desert tortoises in the Mojave Desert. J Wildl Dis 35: 212-238

CRISTALDI M, IERADI AL, UDROIU I, ZILLI R 2004: Comparative evaluation of background micronucleus frequencies in domestic mammals. Mutat Res Genet Toxicol Environ Mutagen 559: 1-9

DESSAUER HC 1970: Blood chemistry of reptiles: Physiological and evolutionary aspects. In: GANS C, PARSONS TS (Eds): Biology of the reptilian. Vol. 3. Academic Press, London and New York, pp.1-72

DUGUY R 1970: Numbers of blood cells and their variations. In: GANS C, PARSONS TS (Eds): Biology of the reptilian. Vol. 3. Academic Press, New York, pp. 93-109

FRYE FL 1991: Hematology as applied to clinical reptile medicine. $2^{\text {nd }}$ ed. In: FRYE FL (Ed.): Reptile care. An atlas of diseases and treatment. TFH Publications Inc., Neptune City, New Jersey, pp. 211-277

GARNER MM, HOMER BL, JACOBSON ER, RASKIN RE, HALL BJ, WEIS WA, BERRY KH 1996: Staining and morphologic features of bone marrow hematopoietic cells in desert tortoises (Gopherus agassizii). Am J Vet Res 57: 1608-1615

HARTMAN FA, LESSLER MA 1964: Erythrocyte measurements in fishes, amphibia and reptiles. Biol Bull 126 : 83-88

HASBUN CR, LAWRENCE AJ, NALDO J, SAMOUR JH, AL-GHAIS SM 1998: Normal blood chemistry of free-living green sea turtles, Chelonia mydas from the United Arab Emirates. Comp Haematol Int 8: 174-177

HUTTON KE, GOODNIGHT CJ 1957: Variations in the blood chemistry of turtles under active and hibernation conditions. Physiol Zool 30: 198-207

JACKSON CG, HOLCOMB CM, JACKSON MM 1974: Aortic calcification, serum calcium, magnesium, sodium and cholesterol in Gopherus polyphemus. Comp Biochem Physiol A. 49: 603-605

JACOBSON ER, GASKIN JM, BROWN MB, HARRIS RK, GARDINER CH, LaPOINTE JL, ADAMS HP, REGGIARDO C 1991: Chronic upper respiratory tract disease of free-ranging desert tortoises (Xerobates agassizii). J Wildl Dis 27: 296-316

KNOTKOVÁ Z, DOUBEK J, KNOTEK Z, HÁJKOVÁ P 2002: Blood cell morphology and plasma biochemistry in Russian tortoises (Agrionemys horsfieldi). Acta Vet Brno 71: 191-198

KÖLLE P, LAMNEK H, HOFFMANN R 1999: Blutwerte bei der Europäischen Sumpfschildkröte (Emys orbicularis). Tierarztl Prax 27: 198-201

LAWRENCE K, HAWKEY C 1986: Seasonal variations in haematological data from Mediterranian tortoises (Testudo graeca and Testudo hermanni) in captivity. Res Vet Sci 40: 225-230

MASAT RJ, DESSAUER HC 1968: Plasma albumins of reptiles. Comp Biochem Physiol 25: 119-128

MASAT RJ, MUSACCHIA XJ 1965: Serum protein concentration changes in the turtle, Chrysemis picta. Comp Biochem Physiol 16: 215-225

MATEO MR, ROBERTS ED, ENRIGHT FM 1984: Morphologic, cytochemical, and functional studies of peripheral blood cells of young healthy American alligators (Alligator mississippiensis). Am J Vet Res 45: 1046-1053

METIN K, TÜRKOZAN O, KARGIN F, KOCA YB, TASKAVAK E, KOCA S 2006: Blood cell morphology and plasma biochemistry of the captive European pond turtle Emys orbicularis. Acta Vet Brno 75: 49-55

MONTALI RJ 1988: Comparative pathology of inflammation in the higher vertebrates (reptiles, birds and mammals). J Comp Pathol 99: 1-26

MUSQUERA S, MASSEGU J, PLANAS J 1976: Blood proteins in turtles (Testudo hermanni, Emys orbicularis and Caretta caretta). Comp Biochem Physiol A 55: 225-230

MURO J, CUENCA R, PASTOR J, VINAS L, LAVIN S 1998: Effects of lithium heparin and tripotassium EDTA on hematologic values of Hermann's tortoises (Testudo hermanni). J Zoo Wildl Med 29: 40-44

PAGÉS T, PEINADO VI, VISCOR G 1992: Seasonal changes in hematology and blood chemistry of the freshwater turtle Mauremys caspica leprosa. Comp Biochem Physiol A 103: 275-278

SAINT GIRONS MC, 1970: In: GANS C (Ed.): Biology of the reptilia. Vol. 3. Academic Press Inc, New York, pp 73-91

SAMOUR H, HOWLETT JC, SILVANOSE C, HASBUN CR, AL-GHAIS SM 1998: Normal haematology of free-living green sea turtles (Chelonia mydas) from the United Arab Emirates. Comp Haematol Int 8: 102-107

SEVINCC, M UĞURTAȘ IH, YILDIRIMHAN HS 2000: Erythrocyte measurements in Lacerta rudis (Reptilia Lacertidae). Turk J Zool 24: 207-209

SYPEK J, BORYSENKO M 1988: In: ROWLEY AF, RATCLIFFE NA (Eds): Vertebrate blood cells. Cambridge University Press, Cambridge, pp. 211-256

TAYLOR RW, JACOBSON ER 1982. Hematology and serum chemistry of the gopher tortoise, (Gopherus polyphemus). Comp Biochem Physiol A 72: 425-428

TAYLOR K, KAPLAN HM 1961: Light microscopy of the blood cells of pseudemyd turtles. Herpetologica 17: 186-192

UĞURTAȘ İH, SEVINÇ M, YILDIRIMHAN HS 2003: Erythrocyte size and morphology of some tortoises and turtles from Turkey. Zool Stud 42: 173-178

WINTROBE MM 1933: Variations in the size and hemoglobin content of erythrocytes in the blood of various vertebrates. Folia Haematol 51: 32-49 
WOOD FE, EBANKS GK 1984: Blood cytology and hematology of the green sea turtle, Chelonia mydas. Herpetologica 40: 331-336

ZAPATA A, LECETA J VILLENA A 1981: Reptilian bone morrow. An ultrastructural study in the Spanish lizard, Lacerta hispanica. J Morphol 168: 137-149

ZUNIGA-GONZALEZ G, TORRES-BUGARIN O, LUNA-AGUIRRE J, GONZALEZ-RODRIGUEZ A, ZAMORA-PEREZ A, GOMEZ-MEDA BC, VENTURA-AGUILAR AJ, RAMOS-IBARRA ML, RAMOSMORA A, ORTIZ GG, GALLEGOS-ARREOLA MP 2000: Spontaneous micronuclei in peripheral blood erythrocytes from 54 animal species (mammals, reptiles and bird): part two. Mutat Res 467: 99-103 
Plate I

Metin K. et al.: Blood Cell ... pp. 163-174
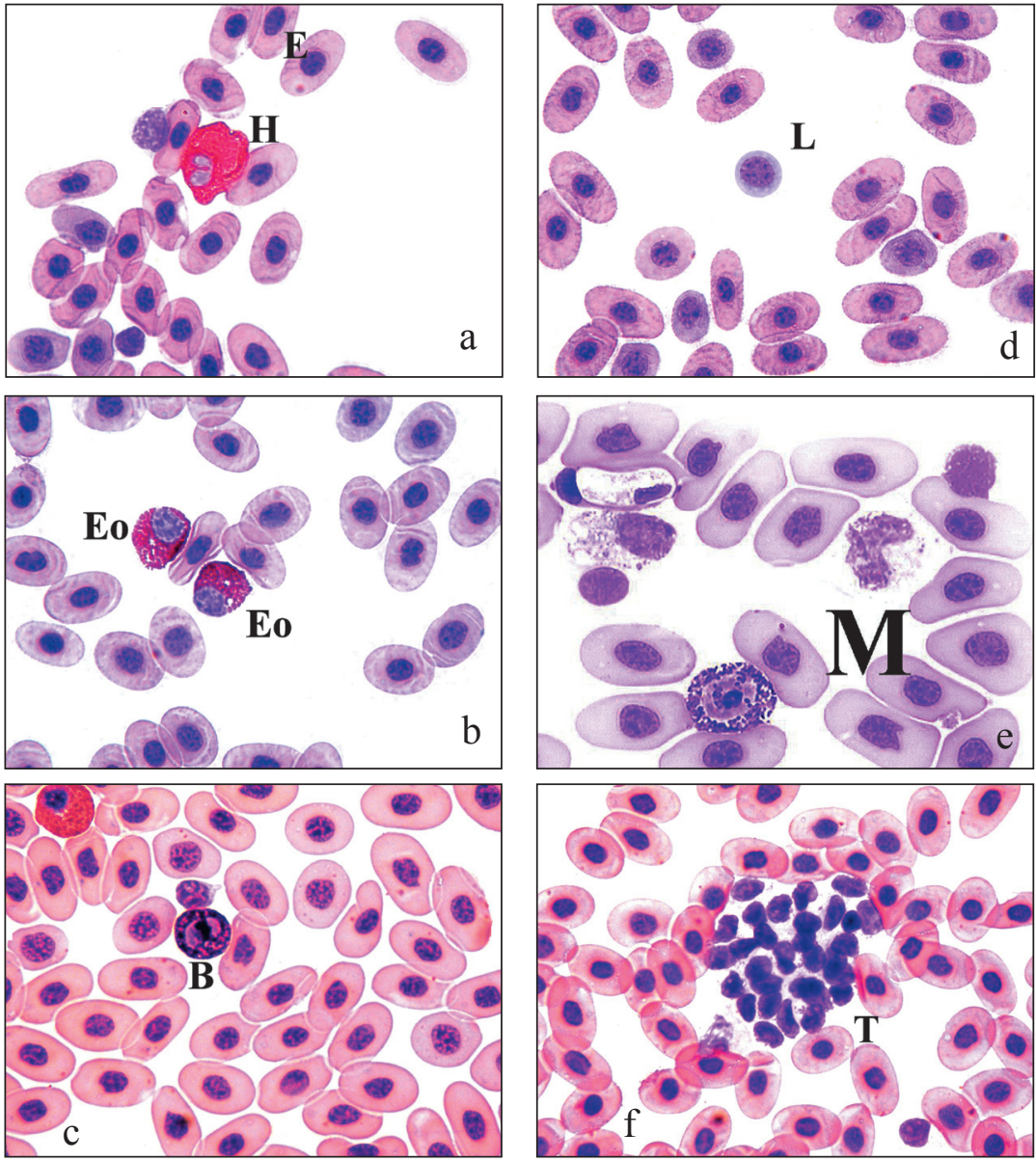

Fig. 1. Blood cells of the captive Caspian turtle, Mauremys caspica

a: Erythrocytes and heterophil (E, H)

b: Eosinophils (Eo)

c: Basophils (B)

d: Lymphocyte (L)

e: Monocyte (M)

f: Thrombocytes (T)

Wright stain, $\times 1000$ 
Plate II
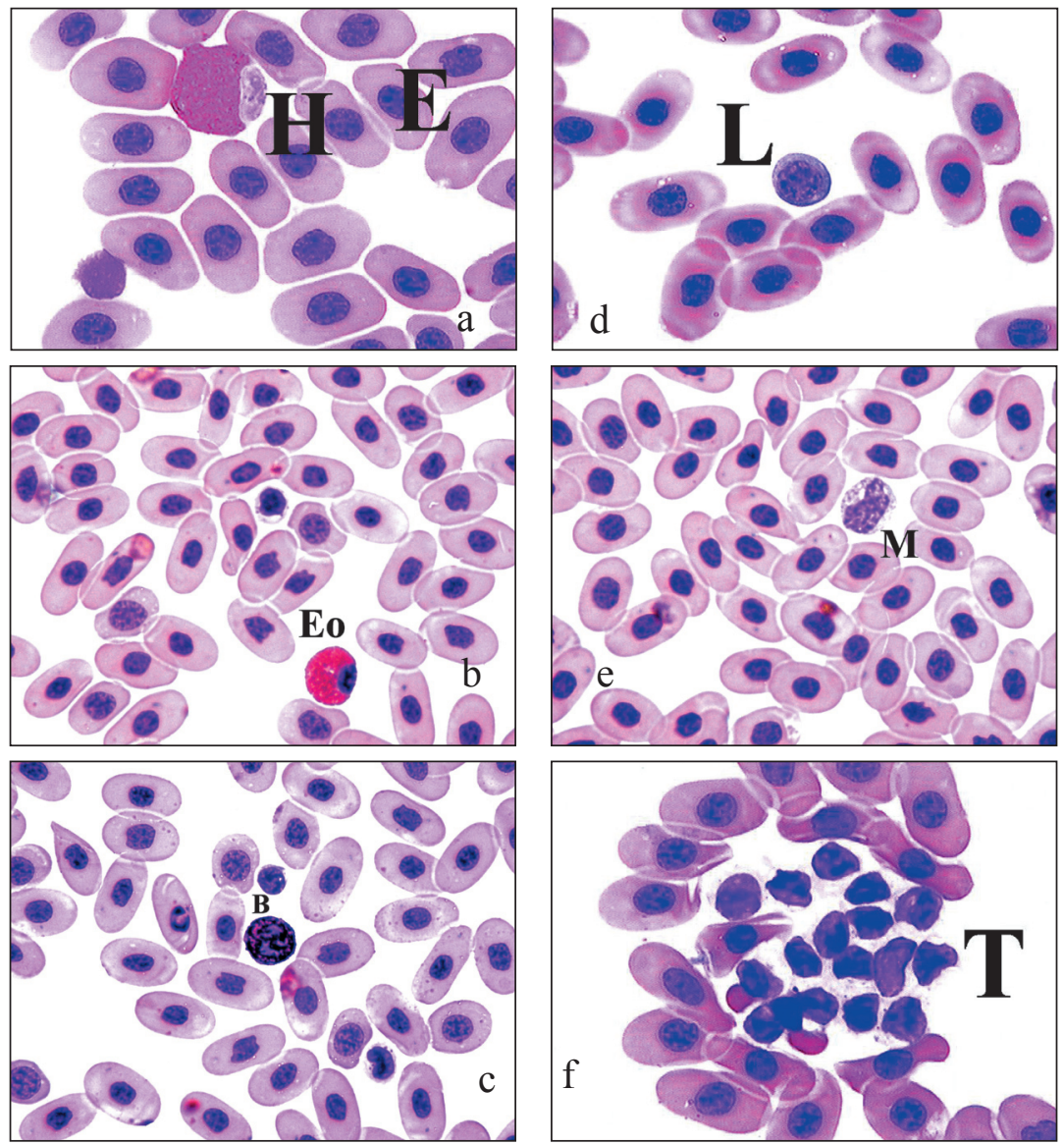

Fig. 2. Blood cells of the captive Balkan terrapin, Mauremys rivulata

a: Erythrocytes and heterophil $(\mathrm{E}, \mathrm{H})$

b: Eosinophils (Eo)

c: Basophils (B)

d: Lymphocyte (L)

e: Monocyte (M)

f: Thrombocytes (T)

Wright stain, $\times 1000$ 